\title{
The design of computer software for learning Latin*
}

\section{Jo-Marie Claassen}

This article formulates a possible theoretical basis for computer-aided learning of Latin. Computer aid cannot be a substitute for conventional teaching, but can offer the sort of selfpaced drill for which a university beginners' course has no time. Spheres of competence to be addressed are: vocabulary, morphology and syntax. Computer exercises must be adapted to the didactic philosophy underlying the general teaching course to which students are subjected. After a brief review of currently available material, the author describes and assesses the success of material produced at the University of Stellenbosch.

Hierdie artikel formuleer 'n moontlike teoretiese basis vir rekenaarhulp vir die aanleer van Latyn. Rekenaarhulp kan nie normale onderrig vervang nie, maar kan die student die soort eie-pas oefening bied waarvoor daar nie binne 'n normale universiteit-beginnersklas tyd is nie. Kennisvaardighede wat aangespreek moet word, is: woordeskat, vormleer en sinsbou. Rekenaaroefeninge moet aangepas word by die onderrigfilosofie onderliggend aan die bepaalde onderrigkursus waaraan studente onderworpe is. $\mathrm{Na}$ ' $n$ kort oorsig oor huidigbeskikbare materiaal, beskryf die outeur rekenaarmateriaal wat by die Universiteit Stellenbosch ontwikkel is, en ondersoek die doeltreffendheid daarvan.

\section{LANGUAGE LEARNING THEORY AND THE DIDACTICS OF CLASSICAL LANGUAGES}

There is no consensus, perhaps there cannot be, about the psychological processes that take place within a learner of language. Opinions are, and always have been, divided about whether a second language is learnt in the same way as the mother tongue, and whether still another learning system obtains in the acquisition of a third or foreign language (Smith 1983, Krashen and Terrell 1983:11-14). Since Krashen, following in the footsteps of De Saussure, first differentiated between language learning and language acquisition (Krashen and Terrell 1983:18-20, 175-7), the many conflicting theories have again been sent in new directions. These directions all have bearing on the challenge to the language teacher: where to begin teaching a language and how to continue in such a way that the learner is most successful. The latest direction is into the field of communicative learning (Krashen and Terrell 1983:17).

The problem appears simpler when the various learning theories are applied to the didactics of the three most foreign of foreign languages: the so-called "dead languages", Latin, Greek and Sanskrit, where interaction with native speakers and the

* Referred to as Computer-aided "dead" language leaming or CA"D"LL in the Department of Latin, University of Stellenbosch, largely as a joke, for the author and her colleagues are strenuously dedicated to showing that Latin is a living and viable part of our cultural heritage. 
communicative approach do not apply. Yet early in this century the direct method and the natural method spilt over from modern language teaching to the Classics. These were followed, also in the Classics, by the audio-oral or audio-linguistic approaches, which became popular in the fifties and sixties, with the advent of language laboratory technology. Adherents of these various methods most often worked within the frameworks of well-articulated theories, closely following lines laid down by theorists of modern language acquisition (e.g. Sweet, undated).

\section{GOALS IN LEARNING AND TEACHING OF CLASSICAL LANGUAGES}

While theories and methods came and went on the fringes, the tried and time-hallowed grammar-translation method still held its own in the teaching of classical languages, with its adherents frequently unaware of or uninterested in formulating any theory either of learning or of teaching (Bruwer 1982:1). These traditionalists appeared instinctively to assume that an adequate description of a language, expounded by paradigm and rule, would be internalized, and so successfully applied by each student that the teacher's often ill-defined goal in teaching and the student's equally undetermined goal in learning would be achieved. Morphology and limited language production were taught as a means towards the development of reading skills.

In Classics teaching, particularly in more traditional schools, the goal was most often taken for granted: to enable the student to manipulate rules for analytical thought about texts, thereby enabling him to translate (which meant decipher) classical texts. A secondary aim, which has of late been largely superseded, was to enable the student to render passages in his native language into the classical language. The material translated needed in no way to relate to the culture of the ancient world.

In South Africa the aim of Latin teaching and learning, in the case of $95 \%$ of its exponents, is far more circumscribed, and therefore easily defined: to enable the student to achieve the standard of proficiency in Latin which is required by statute for aspirants to the Bar (Claassen 1989). This standard of proficiency is about to be fixed (May 1991) by Act of Parliament at either matriculation level, or one year of fully accredited University study. It is still up to each individual university department to determine what content and thrust such a University level course should have. That means that a Latin department can both specify its aim and determine its method of teaching. The latter depends on the learning theory adhered to, either consciously or instinctively, and the degree to which such a department also envisages wider, humanistic aims, to use an old term which has only recently come into play in the context of modern language teaching (cf. Fox ca. 1983).

At the University of Stellenbosch the ultimate goal of any Classics Department was clearly formulated in humanistic terms by Bruwer (1981): "Communication (by the student) with the stimulating world of Graeco-Roman antiquity for the sake of attaining a more profound and complete view of the contemporary Western world." An important aim on the way towards a student's attaining of this overall goal is the development of an ability to read Latin or Greek with understanding. This Bruwer defines as a "grasp of surface meaning" which may be indicated, as in the traditional approach, by means of translation, but also through precise, meaningful quotation and paraphrase, by discussion of auctorial intent, tone and bias, by personal, critical evaluation by the student of the text, or even through analysis of rhetorical style and its function within the text. 
Bruwer lists three basic language skills "of which none should be raised in isolation to an aim itself, but each should be seen as a tool to be employed in the attainment of reading skill." These are the acquisition of a basic vocabulary (Lexis Latina), a cursory command of normal Latin morphology (Formae Latinae), and an ability to distinguish basic structural units (main and subordinate clauses and participial phrases) even where the meaning of some individual words is not yet grasped (cf. Phillips, 1983a:5).

This is not the behavioristic structuralism as applied to Latin language learning by, for instance, Waldo Sweet. ${ }^{2}$ In Bruwer's formulation the emphasis is on recognition and not on production, but it is also on conscious analytical thought, as in the traditional grammar-translation method. To use the current terminology: the cognitive approach is applied to structure in order to facilitate a one-way communication, i.e. reading (cf. Krashen and Terrell, 1983:16). In an environment focused on receptive skills, Burling (1982) argues (in the context of reading a modern foreign language) for language description as a passive skill, subservient to reading. Similarly, Bruwer argues for use of this passive skill, in the form of recognition of morphology, as a tool to facilitate accurate reading. Intelligent reading of Latin is, however, not a passive skill. The student's intellectual effort is applied to recognition of morphology in interaction with semantics (cf. Phillips, 1983a:2). For this reason Bruwer places equal emphasis on the three basic skills, command of lexis, morphology and structure.

\section{4 \\ THE COGNITIVE APPROACH: TOWARDS A PERSONAL MONITOR}

The cognitive approach is applied to communicative language learning by Krashen and Terrell who argue that the learner, by trial and error, develops a personal grammar which acts as monitor to guide his own language production or interpretation (Krashen and Terrell 1983:18, 57, et passim, cf. Burling 1982). Theoretically, the same could also apply to the reading and interpretation of a classical language. Unfortunately in the rapidly-paced learning environment of a compulsory university Latin beginners' course there is little time for the student to develop by trial and error the kind of personal monitor, which should enable him to process instantly all morphological information so as to ascertain structure. For such a student, initial error means failure. In the teaching set-up of a large freshers' class, progress is evaluated by means of weekly tests. Grades achieved ultimately indicate "Pass" or "Fail". The student can therefore not afford to acquire proficiency and ultimate accuracy by means of "gradual elimination of error", as in the communicative learning model postulated by Krashen and Terrell for modern second language learning. Yet, as is commonly accepted, students learn best by doing, and doing is not always accurate the first time around. However, Blair (1982:xi) suggests, and he is not alone in this, that the average language learner can learn faster than has normally been assumed.

What the student needs is some means to exercise his cognitive skills, powers of argument and deduction, his ability to do something with lexis, morphology and structure, in order to gain proficiency and build a personal grammar that will act as monitor in the accurate deduction of meaning (i.e. intelligent reading) of a Latin text. For this purpose, the microcomputer appears to be admirably suited (cf. Geens 1984). Culbertson and Cunningham (1986) stress the development of "higher-order thinking". Last (1984:1-9), discussing the disadvantages and advantages of the microcomputer in language teaching, argues that various teaching strategies should not be mutually

2 Cf. Sweet, Waldo E, Ruth Craig and Gerda Seligson, 1966 Latin, a structural approach. Ann Arbor, University of Michigan P. 
exclusive and that different areas of language learning demand different teaching strategies. This is a point that is often, sadly, ignored.

\section{THE ADVANTAGES OF THE MICROCOMPUTER}

Ideally, the microcomputer has the advantage of liberating the student from a time-table and giving him control over choice of learning areas and self-paced revision (Baume 1985). ${ }^{3}$ A well-constructed program ${ }^{4}$ has the advantage of intense privacy and nonemotional guidance of error (cf. Cook 1984:15-6). This is something different from using technology as a testing and grading assistant, useful as that aspect also can be (Davies 1983). Experts agree that the ability of the microcomputer to store and retrieve information may, in the testing mode, hold a threat to students, offering, on the one hand, psychological blackmail in its manner of feedback, and, on the other hand, the threat of ineradicable evidence of error which may leave them discouraged and debilitated (Jones and Fortescue 1987:81, Russell 1984). It is precisely to free the student from this threat, to give him leeway in building up his own experiential "monitor", by means of "hands-on" practice of grammar, that a good computer program should be designed. Errors should not be held in evidence against the student, but yet the versatility of the computer can be employed to do anonymous or generalized error analysis in order to guide the lecturer towards a better understanding of how students learn, which will influence, in its turn, his classroom methodology (Chapelle and Jameson 1986). At the same time, however, instant feedback, within a program, or perhaps a printout of the analysis of his or her errors, will guide the student towards the ultimate formation of an own personal "monitor" (cf. Cook 1984:4 on "cognitive code learning"). This implies that the computer is important for the students' own formative evaluation, whereas traditional means of testing are more useful for final, or summative evaluation of students' achievement.

There is a great amount of literature on computer-aided language learning, but more on courseware than on theory. This has not changed much since Davis (1983) first made a similar assertion. Martin Phillips (1984a:1 and 1985) calls for theoretical justification for what is attempted, both regarding the unique aspects of computer aid and the desirability of the use of the computer in contrast with other teaching aids (cf. Odendaal 1982). He points out that the elegance of many CA programs conceals their pointlessness. These two observations refer equally well to both the literature about Latin learners and the programs developed for them: there is a number of programs available, there is a body of descriptive literature, but there is almost no theoretical justification for what Latinists are attempting to achieve. Bruwer (1982:1) put it strongly: "Existing Plato Latin courses are in my opinion nothing but attempts to sell sour Falemian as a boxed wine with a fancy plastic tap." Much has, however, been developed in the eight years following this comment and the emphasis has moved from earlier, mainframe programs, such as Plato, to the more versatile microcomputer (cf. Scanlan 1971 with Culley 1989).

3 In this connection, although it relates to the teaching of Mathematics to infants, the work of Papert (1980), a book almost missionary in its infective enthusiasm, is compulsory reading for those still in doubt about the liberating possibilities inherent in CAI.

4 It has become conventional, even in British subject literature, to employ the American word "program" for courseware, reserving the common British spelling "programme" for course of action. 
Latinists do not need to draw only on the current meagre literary resources pertaining to the CA teaching of their subject. They may consult general theoretical work (e.g. HSRC 1983, Robinson, 1985, and for RSA, Wiechers, 1982), work on modern inflected languages like French or Russian, but, more particularly, work on the theory of secondlanguage teaching (Russell, 1984) and of English for special purposes, that is, scientific language. In the case of the latter, focus is strongest on reading, and language description is systemised within narrow confines (Burkart and Burkart 1986, Reinking and Schreiner 1985; Chapelle and Jamieson 1986). Work on the teaching of computer coding ("computer languages") is also useful (e.g. Whitelaw 1984).

There are several very good general books and papers on the design and development of CA programs as teaching material, which all cover roughly the same ground (Last 1984, Phillips 1983b, 1984a and b, Higgins and Johns 1984, Jones \& Fortescue 1987, Burkhardt and Frazer undated, ca. 1985, Murray, Morgenstern and Furstenburg 1989). Important aspects of design are the following:

(1) program focus need not coincide with learner focus, that is, language acquisition may appear incidental to the development of some other skill;

(2) the degree of difficulty of program design (rigour of procedure) is independent of the complexity of its content material;

(3) a variety of program styles may be adapted to a variety of learning styles;

(4) classroom management may be varied to accommodate group activity;

(5) programs may be either context-dependent or may be based on simple recognition, or may promote recall, comprehension or constructive understanding.

In all, dynamic interaction by the learner with the machine is a far cry from the postulated habit-formation of programmed instruction which informed the theory for early attempts at CALI (cf. Phillips 1985).

Burkhardt and Frazer (undated: 35) point to the basic tension between the range and flexibility of program design options and their simplicity and clarity. In a hierarchy of learner needs, the programmer can adapt both program style ("procedure", which may be more rigorous, or less so) and intellectual content ("argument", which may be more complex, or less so). ${ }^{5}$

\section{EXTANT LATIN COURSEWARE ${ }^{6}$}

In my observation of existing Latin courseware, which most often is of the testing or quiztype, I have come to the conclusion that the types of programs decried by Bruwer have one or more of the following characteristic drawbacks:

(1) rigorous procedures (largely involving complex feedback on errors to both learner and teacher) offering elementary content (Rubenstein, Kerschenbaum). These,

6 See listing of software after the Bibliography. Only programs personally evaluated by the author or an assistant have been listed. Each item is accompanied by a brief evaluative description. Not all programs listed there will be referred to below. See Bibliography for listing of annually updated catalogues. 
although showing up learners' weaknesses, will bring them no nearer the aims spelt out by Bruwer, but will merely give greater facility in the production of Latin morphology;

(2) lack of clarity in the aim of the procedural design which has as principle the requirement that a student fill in morphological paradigms, with the general assumption as background that testing and teaching are basically equivalent (Latousek, Scanlan); ${ }^{\top}$

(3) monotony of approach, which may soon induce extreme boredom in the student, even where the program has a sound learning theory as basis (Cairns);

(4) the presentation of the learning material in fragments, a drawback equally inherent in the presentation of Latin morphology in paradigms in the traditional grammartranslation method, where students experience extreme difficulty in movement from production of forms to recognition of these forms in literary context (cf. comments by Culley 1989$) ;^{8}$

(5) irritating "bells and whistles," or trite and even insulting remarks (Kershenbaum 1986).

Each of these drawbacks is open to remedy: drawback number (1) may be improved by enhancement of the quality of content of such a program, coupled with greater variety of approach; (2) requires the procedural rigour of (1), emphasizing to the student the need to learn from his mistakes, and to relax the requirement that a score which may be used in evidence against him must be reported to the teacher; numbers (3) and (4) may be circumvented by variation of approach, including some manner of CA enhancement of reading skills, in contrast to mere reproduction of morphology; the fifth may be emended or eliminated.

The array of programs generated and continually being updated at the University of Delaware, Newark, DE, (Culley 1978) offers a variety of approaches and exhibits an admirable degree of versatility, which will obviate the boredom, easily generated in students by a single approach.

Programs which show the greatest procedural rigour in design are those that depend on so-called Artificial intelligence - where an in-built parser itself manipulates the material offered the student. Such programs may be termed, in the long run, "programmerfriendly" as, after initial input, they can generate many hours of student-focused tasks. Procedures following some type of Listing Production ${ }^{9}$ appear to be most popular (Cairns, Kerschenbaum, Culley's Latin Skills). Emanuelli (1986) suggests that the

7 Davies 1983 asserts that we don't really know what we are doing with CAL testing. This is largely true. Much program development is based more on instinct than on scientific observation.

8 This applies to most programs which require morphological fill in, e.g. Rubenstein, Latousek.

9 Listing Production means that the machine is working out the answers at the same time as the student, in contrast to the so-called customized mode which works with whole units of data which have been programmed in by hand. Cairns' LLCP is written in LISP, a specific AI language, which is implemented in UO-LISP. Kershenbaum uses an individually-devised listing procedure originally programmed in BASIC. Although these were initially designed for CAI, both authors plan to refine their systems in order to be able to parse whole texts for purposes of research. 
student's learning environment can be enriched by making him teach the machine, using AI techniques (so also Phillips 1985; Paramskas 1986).

At the other end of the spectrum the least programmer-friendly are those utilizing some form of hypertext, where, given the present state of computing expertise, a great deal of material needs to be put in by hand (cf. Kussler 1989). Such programs are versatile. Ideally, they cater for a hierarchy of student needs. They are often, however, extremely bulky, and a program such as TUTRIX (Latousek) in the end manages to process a mere thirty lines or so of Latin verse for the student's edification. Such a program appears to be aimed at substituting not for a single book of commentary, but for a whole library. 10 The student can, at will, call up layer upon layer of information, go into a quiz mode or record his own comments and receive a printout of his errors. They are extremely bulky to produce, and therefore hazardous to install and operate. Some of these programs are at present more of a gleam in the programmer's eye than a reality. ${ }^{11}$

\section{DESIGN SPECIFICATIONS}

Between these extremes lies the possibility of developing a series of smaller programs, each with a limited aim and all variants on some of the basic characteristics of studentcomputer interaction, such as the possibility to randomize and repeat the same exercise indefinitely, limited feedback on both correct and incorrect responses, and a scoring system which enables a student to compete with his own previous score: that is, utilization of a "testing mode" in order to simulate a game-format challenge as incentive (Higgins 1984).

Here too the programmer must be clear on the learning skills that he wishes to enhance, and must at least attempt to formulate a learning theory, whereby he will be operating. This is particularly true for the classics teacher who must rethink traditional assumptions about classical language acquisition and decide what, if any, of the theories of modern language acquisition can be applied or adapted. Cook (1984:11) suggests that (modern) language acquisition can be more fruitfully looked at by distinguishing "levels of processing information" than by following the "listening-speaking-reading-writing" model (of which only the last two traditionally apply to classical languages).

Cook distinguishes seven levels: (1) letters (2) word units (3) syntax (4) minor topical unit (paragraph) (5) major topical unit (6) discourse (both conversation and continuous texts) (7) "pragmatic meaning" i.e. context. Cook suggests that different approaches to these levels, except perhaps the last, can all be handled by the computer, by utilizing a variety of techniques. Cook's observations are even more important in the context of a language which is read rather than spoken or written. For the purpose of this paper, I accept his divisions, even if the rigid stratification of his higher levels may lay him open to criticism. If his acquisition model is applied to the learning and teaching of the classical languages, levels two to four may be seen to agree roughly with the three "tools" postulated by Bruwer (1981), which would leave the fifth, sixth and seventh levels to be handled by the teacher, unstratified, in a classroom situation.

I do not here wish to enter the debate on the parsing of computer texts, so refrain from further comment.

10 The GLOSSA authoring system works in an hypertext authoring mode, which enables the teacher to enter his own text and imbed levels of information.

11 Culley intends with his LIBER hypertext to incorporate all the AI features of his other learning packages for grammatical analysis, as well as putting in by hand the type of literary commentary suitable for undergraduates, in a program that will feature large sections of the Latin literary corpus. 


\subsection{Aims and specifications}

When, about five years ago, members of the Latin Department at Stellenbosch University decided to explore the use of the computer to supplement the rapid teaching pace of a Latin beginners' course (Claassen 1989) we decided immediately to explore two computing modes.

The first computing mode would be an automatic, randomizing test-feedback mode for enhancing lexical and morphological study (levels two and three above), which would offer dynamic interaction with basic learning material. This would be offered in the same format as the written tests which had been standardized by Bruwer and others from the late $1970 \mathrm{~s}$, after the completion of a series of methodological experiments (Claassen 1987). Davies (1983:34) discusses criteria for testing and calls for tests that pit an individual against himself, for the sake of diagnosis, i.e. the indication of areas of insufficient proficiency. Such a mode would be ideally suited to achieve this aim.

The second computing mode would offer cognitive analysis and synthesis of structure, utilizing the dynamism of the computer, particularly the possibility of colour-change instead of verbal description. Colour-coding, which underscores differences in sentence structure, is one of a series of visual devices in the context of Latin teaching. Seeing the colour change in response to correct input would reinforce a correct response, but, more importantly, would nudge the student towards more intuitive recognition of structure, and therefore towards understanding of the text and grasp of meaning. Cook's level three would be the object of such a learning programme, but attention would also be paid to the fourth and fifth levels: unity of topic within a paragraph. This would work on an interlanguage level, testing understanding of Latin verbal relationships without necessarily resorting to meaning, an area that Davies in 1983 regarded as then not yet addressed by CAI.

Initially it was felt that speed in the facilitation of the system was essential, and that the first programs to be produced should not be technically rigorous, nor the content academically very complex.

\subsection{QUEST and $\mathrm{C} \cdot \mathrm{O} \cdot \mathrm{N} \cdot \mathrm{S} \cdot \mathrm{E} \cdot \mathrm{N} \cdot \mathrm{S} \cdot \mathrm{U} \cdot \mathrm{S}$}

The QUEST ${ }^{12}$ didactic authoring package offers the possibility of easy record-keeping. It was decided that the first type of program would be run within such a system. A schoolleaver, with considerable background in personal computer programming, was employed as programmer for the framework of each of four programs, but it was not the intention that he should type in all the data (content of each drill) to be employed. It was hoped that such data could more easily and cheaply be typed in by departmental typists or junior assistants. Consequently, he devised three different test-and-feedback frameworks in TURBO-PASCAL, and a cloze-type exercise, which he imbedded within a QUEST

12 Published by Allen Communication, (c) 1986. This system has some disadvantages: for instance, students have to be individually registered, and have to re-enter the program after each exercise. In 1991 this framework was replaced with a simpler subpackage, written in TURBO-PASCAL, which also records student performance in terms of time spent on the exercises. 
setting, and which each in turn could call up (unformatted or text) data files typed on an ordinary monochrome computer, using any word processor, e.g. MS WORD. This didactic framework has recently been discarded in favour of a customized setting which is simpler to use and which records total time spent on the computer by individual students (in addition to scores achieved as in the previous system). The series of four randomizing programs are now offered as a neat package entitled $\mathrm{C} \cdot \mathrm{O} \cdot \mathrm{N} \cdot \mathrm{S} \cdot \mathrm{E} \cdot \mathrm{N} \cdot \mathrm{S} \cdot \mathrm{U} \cdot \mathrm{S}$ (as they work on the principle of agreement between what the student feeds in and what the computer has been programmed to know).

The didactic principle of all these programs is the same: that "testing" is merely a gameformat device which allows for active manipulation by both students and the computer of material that is to be memorized (cf. Davies 1983, Higgins 1984) This implies that in each frame which appears on the screen students must be offered more material to learn than they are tested on; that the testing is merely a means of eliciting interaction from students with the machine, and that scoring is merely a challenge to the students upon which to improve.

\subsubsection{Random omission}

Two of these programmes, VERBA and ARSGRAM, work in exactly the same way. The first offers the "dictionary details" of a series of Latin words, fifteen in succession (drawn at random from a pool of between thirty and forty words with their dictionary details) from which one element has been omitted at random. Each such set comprises vocabulary to be learnt in a particular week in the academic year. The frame can however be applied to any vocabulary list which is compiled to fulfil a particular need.

The second program, ARSGRAM, offers a menu of sets of data, such as nouns, verbs, adjectives, from which the student chooses the set on which he wants to concentrate. ARSGRAM offers, in a column, a traditional paradigm, verbal or nominal, or perhaps noun plus adjective, where again one element is omitted at random. The student must type in the missing element. After three erroneous attempts by the student, the machine gives the correct response and moves on to the next item. Errors are listed at the bottom of the screen, with a clear indication that they were incorrect.

In both these programs, the omitted element, when correctly produced by either the student or the machine, is highlighted in red in its correct position in the series. VERBA is programmed in such a way that any of a half a dozen meanings, in either English or Afrikaans (and in a pilot project, some in Xhosa), if included in the data file for a particular word, will trigger acceptance. The initiators remain conscious that lists are by no means the ideal way to inculcate vocabulary, and that, ideally, the meaning of words should not be considered as a learnable absolute (cf. Louw 1989 and Phillips 1983a). Yet the program is successful, easily updatable and saves classroom time for higher-level exposition.

\subsubsection{Multiple choice}

The third of these programs, FORMAE, is once again based on a testing method employed within the department: it works on the principle of a challenge to the student to identify, in a multiple-choice format, the morphological form complying with a given grammatical description. Here too a TURBO-PASCAL program drives a random call-up of fifteen examples from files of about 45 examples each. Again data was typed in unformatted on the MS WORD processing system, but the compllation was slightly more arduous: a professional Latinist set up the tests and, for feedback, each word in each set of five (the correct response plus the four distractors) is provided with a two-line 
analytical description. After each incorrect response, the analysis of a particular distractor appears on the screen in a contrasting colour: after the third incorrect response, or immediately after a correct response, the description of all five words appears in glowing white on the screen, with the correct response which complies with the original challenge.

\subsection{Computer dynamics}

The principle of all three these programs is not to teach work which the student has never met up with before, nor simply to test over-familiar work, but to use computer dynamics to turn the drill or studying phase, which precedes language assimilation, into a challenge. This will encourage active thought about the material to be memorized.

In each case more material is taught than tested: the students may initially assume they are being tested, but they soon realize that there is at any given moment more material being offered than they are challenged to produce. ${ }^{13}$ After their third incorrect attempt, they are also not allowed to perpetuate errors or to flounder indefinitely, but may contrast their own incorrect responses with the correct answer which the machine provides.

The different screen layout of the three systems alleviates monotony, and, as there is no attempt at structuring access, students are free to choose both the program, and the content, on which they wish to concentrate at any session, and also the length of time, they wish to devote to it. A single datafile may be re-used almost indefinitely, as the random call-up of sets in all three systems, plus the randomized challenge of omitted items in VERBA and ARSGRAM, lead to almost infinite variety. A student may work over one file until he consistently achieves $100 \%$. In the meantime he has actively mastered far more linguistic information than he has been challenged to produce. The didactic set-up informs him both of his achievement, expressed as a percentage (firsttime correct responses carry a higher mark) and the time he expended on a particular file.

\subsection{Cloze-technique: practice and theory}

Included in the package of four programs is another, entitled ARS SCRIBENDI. The same basic TURBO-PASCAL driving system has also been adapted to produce simple cloze-type exercises, once again based on familiar work: in this case the actual Latin texts read by the students (from the Vulgate new Testament, Balme's adaptation of Petronius' Satyricon, or from Nepos' Vita Hannibalis). Each chapter from the student's reading text appears as a file. In this case the production of data is even more economical as two of

13 The program lends itself easily to a multilingual approach, as the randomizing framework can take data typed in any of a multitude of languages. At present the vocabulary exercises offer students a choice between Latin-Afrikaans-English and Latin-Xhosa-Afrikaans-English, the morphology program can be run in either English or Afrikaans, and the paradigm program offers bilingual (Afrikaans-English) designations. The cloze program (see below) is, of course, solely in Latin, but bilingual instructions are attached. The customized structural analysis programs use Afrikaans as teaching medium (see below), but one of each type of program is offered in English. 
these texts had originally been produced within the department, using MS WORD. ${ }^{14}$ The chapters were simply taken over, edited into a consistent format and saved unformatted. Each chapter is no longer than one screenful of data.

Here the program omits at random intervals the last two letters of any word. The students must complete the blanks. A correct response is immediately accepted in a contrasting colour: an incorrect response is not accepted and a flashing device indicates to think again. After a third unsuccessful attempt the correct ending flashes intermittently in red until a move is made on to the next text.

The theoretical rationale for this program is different from the preceding: it was long held that writing in Latin or translating into Latin is a good training for understanding and reading Latin texts. Hence the importance of so-called prose composition in traditional grammar-translation courses. Student production of correct Latin has however many variable impediments: insufficient vocabulary, inexpert grasp of the meaning of the original to be translated, poor command of morphology, incorrect spelling and total ignorance of the idiomatic feel of Latin style. Also, the basic premise has of recent years been doubted. There may be less connection between production and understanding of Latin sentences than formerly thought. Writing in Latin is definitely not one of the final aims of learning the language. At Stellenbosch and in the requirement for matriculation of the Cape Education Department the practice of a Latin prose composition has for these reasons been discontinued.

It is, however, agreed that writing in Latin under control of the teacher is a good teaching aid, particularly where the variables can by some means be overcome. The cloze technique, whereby a familiar text is only partly deleted, is a well-known exercise in some of the more recent Latin text-books: the computer makes it possible to aid a student in the partial production (in reality the reproduction) of an idiomatically and grammatically sound Latin text. Students must be able to read the text correctly and interpret the structural hints provided by the inflections of the remaining words of a text in order to know what the omitted morphological form should be. Although most inflected endings of words comprise more than two letters, it was decided that omission of the last two letters would offer sufficient challenge to students and also permit omission of frequently occurring short words. If both letters of a two letter-word should have been randomly omitted, they must still understand enough of the text to be able to distinguish whether, for example, a conjunction is required, to give coherence to the structure of the passage, and whether this should be the coordinating conjunction et or the subordinating conjunction $u t$ (which requires a different verbal form to follow it), or whether the omitted word is a preposition, say, either ex or ad (which have opposite meanings). Of importance here is the fact that the random omission is aimed merely at giving students the opportunity of dynamic interaction with a text. Students think they are focusing on the omitted letters. They are in fact working with the text as a whole.

This exercise therefore enables the limited production of Latin words to work as a test of understanding, while it helps the student to come to grips with the basic difference between Afrikaans or English and Latin: that morphology, not word order, influences meaning. Incidentally, the exercise aids students to prepare a passage in a dynamic way for more conventional testing within the normal departmental examination framework.

These very simple programs have the advantage that with limited expenditure of programming effort, a great variety of students' needs can be addressed, and that data files may with very little trouble be altered, added or devised anew by the Latinist, who needs no expert computing knowledge in order to do so. We are aware of the fact that

14 The program lends itself to customizing, and texts can easily be taken from the CD ROM collection of classical texts (Hewlett-Packard). 
lists of words are by no means the ideal way to learn vocabulary, nor repetition of morphological paradigms the best way to learn grammar, but these are short cuts, aids to be exploited by students, on their own, in their own time. These short cuts free the lecturer's class-time for higher-level exposition and meaningful textual, even literary, study.

\subsection{Colour coding to inculcate sentence structure}

The rapid pace of a compulsory university beginner's Latin course leaves some students, however, with an incomplete grasp of the basis of reading techniques as exploited in the classroom. For these students a different set of computer exercises was devised, using TENCORE as authoring language. These exercises were also imbedded into the same didactic format. Here material was written by a Latinist and content and process were programmed as organic units, which can only be updated by new programming. As basis was used the structural teaching strategy developed by the late Professors Smuts and Bruwer from Sweet's behavioristic pattern-model into a cognitive model of structure. This teaching strategy comprises awakening students' awareness of sentence structure as a function of the nature of the Latin verb, a case of morphology dependent on lexis. Students are encouraged to see the Latin verb as the structural growth point of the sentence. The meaning of a verb gives rise to the development if one of six types of sentence structure, influencing the occurrence of nouns in various forms (or cases), recognizable from the endings of these words. ${ }^{15}$

Recognition of structure is the last in the logical series lexis $\rightarrow$ morphology $\rightarrow$ morphological description allied to sentence function $\rightarrow$ complete sentence structure. In these programs, students are guided by means of multiple choice questions (and corrective feedback along the way) to recognise the particular structure of a model sentence, which is produced on the screen in a distinctive colour, after which they are challenged to identify similar structures in a pool of sentences with varying structures. Correct identification causes a sentence to change to the colour of the model.

Upon completion of this phase, a second model sentence with a different structure is similarly presented for analysis, and its type again identified in a different colour. In this way students go on to identify structures, until they have at last fished out all similar structures in the pool. At the end the pool (which may comprise a complete little story) appears in a rainbow of colours. At this stage students again need to think actively about why adjacent sentences are coloured differently. If they are still in doubt, they have the option to repeat the exercise (which starts in a teaching mode) or they may proceed to another, similar exercise. Again the choice of time allocation is left to the students, but the format of the program is strictly structured.

A program using the same authoring technique, but this time illustrating extensions to the noun (adjective, possessive nouns or adjectival clauses) also makes use of colour change to bring home structural similarities. Here the exigencies of the grammatical points to be illustrated require compilation into columns, which appear progressively below the text on the screen as students correctly identify agreement, say, of noun and adjective, or the relationship between a noun and a possessive.

15 The six structures depend on six verb types: (a) intransitive verbs, (b) transitive verbs, (c) the verb to be used as copulative or absolutely, (d) impersonal verbs, (e) auxiliary verbs and those requiring an infinitive to complete their meaning, (f) passive verbs. 


\subsection{Evaluation}

An important aspect of the development of teaching material ${ }^{16}$ is evaluation, both progressive (formative) and summative. ${ }^{17}$ It is generally agreed that material cannot be perfected in isolation, but needs student feedback for improvement or adaptation of both format or content (Locatis and Atkinson, 1984:258). When this project was first begun, the author assumed that there would be suitable software available from overseas, and that evaluation would mainly entail comparison of alternatives before the wide-scale adoption of a ready-made program. The need for such a program to comply with local conditions, that is, both teaching medium and, particularly, didactic philosophy, soon showed that such an evaluation would be totally inadequate (Claassen 1989b). Much valuable insight was gained, however, from evaluation of such programs by a series of student assistants, but this was mostly in the field of program design, with particular reference to "don'ts".

Student feedback may be formal, that is, it may be purposefully elicited in the form of a questionnaire, ${ }^{18}$ or by criterion-referenced post-testing (Boettcher et al 1981), or it may be informal, garnered in personal encounters with students. ${ }^{19}$ It may also be integral to the working of a program; that is, interpretation of scoring within the QUEST didactic system, or the new customized scoring-system initiated in 1991, will indicate how well material has been mastered. A third method of evaluation makes use of a non-

16 Also reportage in order to gain feedback from colleagues. The didactic wheel not only runs a treadmill, but is frequently reinvented for lack of communication, Novak and Gowin 1984:174.

17 Boshoff (1989) distinguishes three categories of criteria: neatness of programming, usefulness of content, and didactic effectiveness; Reeves and Lent (1982) speak of levels of evaluation: documentation, formative review and operational testing, assessment of immediate learner effectiveness and impact evaluation on the long term. A useful checklist is to be found in part 4 of the HSRC Report (1983:335-68) on The computer in education and training Phillips (1983b) offers an equally useful matrix for the categorization of CALL programs according to a non-sacrosanct taxonomic system. Very few effectiveness studies cover all aspects of evaluation, but there seems to be consensus that the human factor does and should loom large in all such evaluation. Chapelle and Jamieson (1986) stress unquantifiable variables which influence student performance and therefore make evaluation difficult. Boettcher et al. (1981) report on a comparison between CALL and the printed word, in which the former proved more effective.

18 Most significant is the almost consistent student comment, elicited at the end of 1989 from successful participants, that "they would have put in more time on the computer" if they could have relived the past. Cf. Hart 1989.

19 Students questioned report enthusiastically that "they would not have made it without the computer". This appears to apply particularly to students from disadvantaged backgrounds. Baume (1985) reports similar improvement where traditional instruction in French was enhanced with CAI, similarly favourable comments on the CA programs, and also increased acceptance by students of the need to learn grammar. Hart (1989) reports similarly about a CA Spanish course, but also reports some negative response, as "too time-consuming" and "problems with typing". 
performing control group. ${ }^{20}$ All three systems may be used either progressively or summatively. A fourth method, which is employed, apparently very successfully, at the University of Delaware, is for both author and programmer to watch a particularly articulate student work through a newly perfected program, and to react to his suggestions on both creative levels.

Formative evaluation is a necessary component of program development, but often results in student frustration, as errors can be eliminated only after feedback. ${ }^{21}$ Some students were put off by these unavoidable hiccups, others stopped using the system as a result of pressure of work. It was felt that the CA"D"LL programs could not be made compulsory until they were error-free. During the first three years computer work was totally voluntary, but in 1990 a system of bonus marking was introduced, students being awarded up to $5 \%$ for faithful practice. In 1991 completion of CA"D"LL will simply comprise $5 \%$ of students' class mark. The criterion will not be proficiency, but time spent on these exercises, for experience (backed by explicit feedback from successful participants) has shown that there is a direct correlation between length of time spent on these exercises, and degree of success.

A series of four annual cycles is comparatively short for summative didactic evaluation. Attempts at summative evaluation by means of periodic control of student performance were made during 1989 and 1990,22 using as control groups students who had not availed themselves of the computer exercises. In each case numbers were rather small, as a result of the factors outlined above, yet a consistent pattern emerged, complying with the more informal evaluation of the previous two years. Graphs drawn of Latin students' examination results over the period of one academic year in 1989 and again in 1990 (see Figure 1 on p.18), show that those who made regular use of CA"D"LL seem to have attained better results than those who did not. An interesting feature is that in all four years two distinct groups of students appear to benefit more by the CA"D"LL approach: the very best and the weakest. Of the latter, no students from the control groups passed Latin at the end of the year, ${ }^{23}$ whereas at least some of the workers were successful. In both years in the group that started off with marks between $35 \%$ and $55 \%$ the non-

20 The traditional scientific method used extensively to give educational research an aura of respectability is now recognised as based on two faulty assumptions: that there is uniformity in both students and CALL (Chapelle and Jamieson 1986). It must be approached with care. Silberman (1970:412 et passim) makes out a strong case for de-scientificating educational research, and Novak and Gowin (1984:1974ff.) advocate recognition of the "relativity and supercedability of knowledge about education."

21 Locatis and Atkinson (1984:258) consider student try-out a necessary part of debugging.

22 In both 1989 and 1990 marks achieved in Latin tests in April were used to select homogeneous groups: weak students achieving an average of $45 \%$, average with $60 \%$ in April, better students achieving 70 , and very good, averaging $85 \%$. Students' performance in June, September and November were compared with control groups of similar ability. The author does not pretend that these figures are statistically significant, as both participant and control groups were very small. The great degree of correspondence in pattern over two years, which agreed with the informal findings of the previous two cycles, is perhaps more significant.

23 The standard university pass mark of $50 \%$ is usuaily not high enough to ensure successful performance in the following Latin I course, but it is beyond departmental control to set a higher standard. 
workers ended with an average of about $20 \%$ lower than the workers. At the upper end of the scale, those brighter students who kept working on the computer continued to achieve consistently high marks, whereas their peers as non-workers, although still successful, scored significantly lower. For students of average or slightly better ability, the difference between the two groups was not so great. In both years there was a tendency for the two middle control groups to surpass the computer-workers in June, after which their performance deteriorated, picking up again slightly by the end of the year, but still not achieving at the same level.

As the graphs show, on average there was a clear pattern of benefit accruing from consistent computer practice. There were, however, exceptions among both the workers and the non-workers, ${ }^{24}$ consistent with what may be termed the non-quantifiable human factor. In the case of Latin studies, the human factor is complicated by the fact that Latin is a compulsory subject for aspirant lawyers, and consequently carries with it considerable emotional baggage, often of a negative nature. Other non-quantifiable aspects appear to be inter alia the following:

1. Students who worked regularly on the computer programs, might have been more diligent in any case, i.e., even without CA"D"LL they might have been more successful than the others.

2. Students who were not interested in working on the computer often had no interest in Latin as such, and the latter rather than the former could result in failure.

It is clear, however, that students who either do not know how to study or do not want to study definitely show better results when they are guided into doing systematic work with CA"D"LL, and that good students retain a higher, more consistent standard of excellence when aided by the computer. In the light of these findings, the Department of Latin at Stellenbosch University feels that the amount of effort and expense involved in the initial development of these programs has been justified. They have now become an integral part of its teaching programme. The challenge is now to make all Latin students aware of the advantages of CA"D"LL, so that all can experience in practice what has been demonstrated by a small number, that Computer Aid is one way of making "Dead" Language Learning come alive. ${ }^{25}$

24 Sometimes individual results show an opposite tendency: in 1990 Student X, who worked fairly consistently on the computer, started with $54 \%$ in April but in his last exam achieved $38 \%$, while Student Y, a control non-worker, also started at $54 \%$ but achieved $56 \%$ as a final mark. This implies that a student who works effectively at home does not necessarily need computer aid to do well or to improve. The human factor can never be totally eliminated, and individual discrepancies do not invalidate general findings. Cf. Chapelle and Jamieson (1986) and n. 17 above.

25 Many people and institutions have, during the course of four years, contributed to the work in hand. Particular thanks to my colleagues in the Department of Latin, especially Carina Malan and Elva Zietsman, a series of assistants, of whom Suzie Joubert was the last and most efficient, and computer experts Dr MM Malan, Marie van Zyl, Suzanne Macdonald, Veda Raubenheimer and Daan Claassen. The cooperation of colleagues at other universities, notably the Western Cape, Delaware (Newark DE), Brooklyn College (NY), Cambridge and Leeds, England, is much appreciated. Gratitude is expressed to the Research Administration of Stellenbosch University, its Bureau for University and Continuing Education, and its former Institute for Language Teaching, for extensive financial support, and to the editor of PER LINGUAM for extreme patience. Finally, thanks to those many Latin Beginners' students who were our inspiration, our guinea pigs, and our guides. 


\section{FIGURE 1}
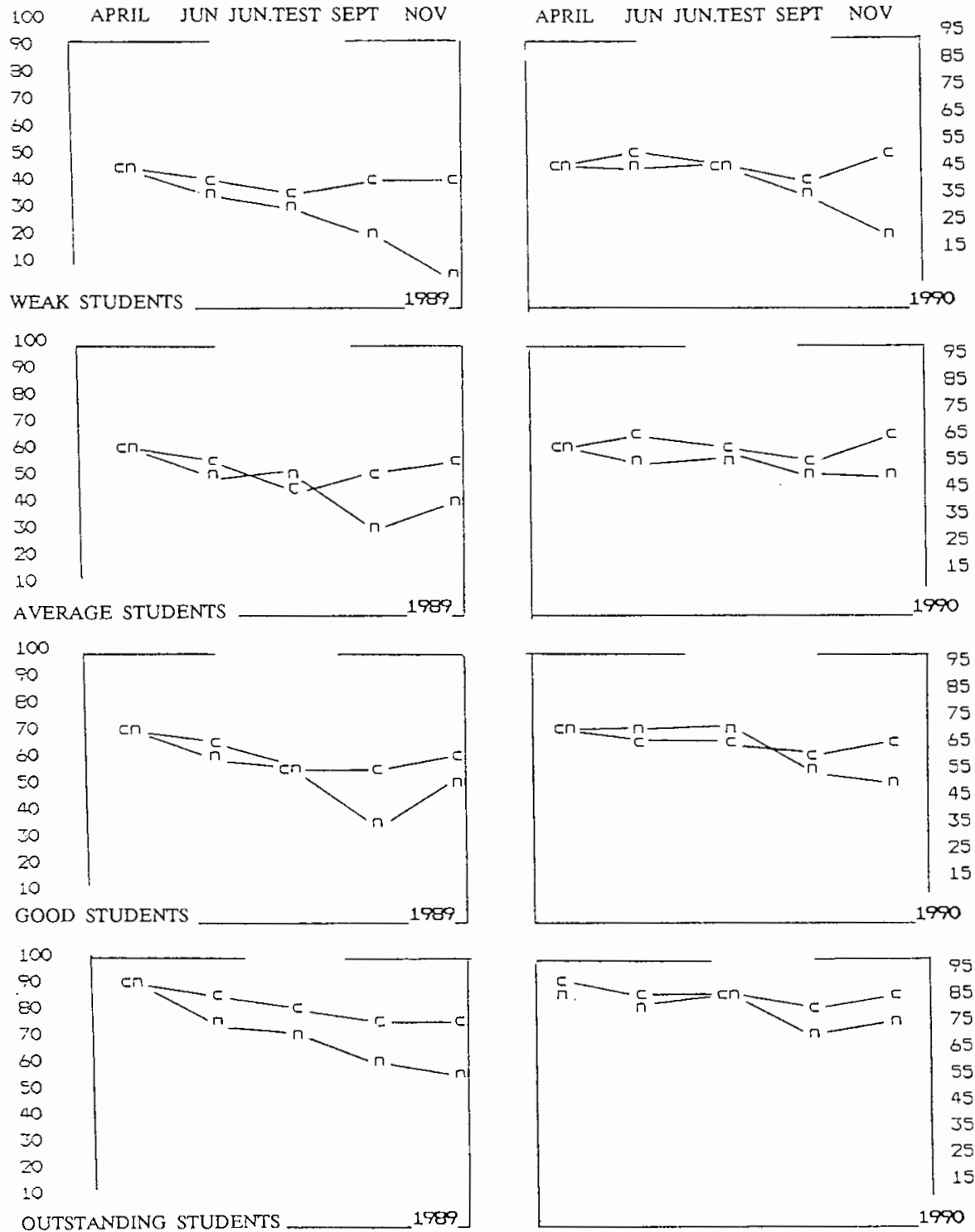

COMPUTER-AIDED STUDENT PERFORMANCE IN BEGINNERS' LATIN (C) COMPARED WITH PERFORMANCE OF STUDENTS WHO DID NOT MAKE USE OF THE COMPUTER (N) 


\section{BIBLIOGRAPHY}

\section{Books and Articles}

BLAIR, R.W. 1982. Introduction: in Innovative approaches to language teaching. Rowley, Mass: Newbury Pub.

BAUME, GEORGES J.R. 1982. Computer-assisted language learning: a pilot experiment. Modern Languages 66.1, 50-57.

BRAIDIE, SUSAN M. 1989. Modern adventures in Ancient Rome. Enquiry: Research at the University of Delaware, Newark DE. Winter 88-89, 16-21.

BOETTCHER, ELAINE F., Sylvia, F. Alderson and Michael Sacucci. 1981. A comparison of the effects of computer-assisted instruction versus printed instruction on student learning in the cognitive categories of knowledge and application. ADCIS Journal 8.1, 13-17.

BOSHOFF, C.J. 1989. Kriteria en prosedures vir die evaluering van rekenaargesteunde onder rigprogrammatuur. SA Journal of Higher Education 3.2, 115-21.

BRUWER, S.M. 1981. Memorandum insake die gebruik van die rekenaar as onderrighulpmiddel t.o.v. Latyn. Unpublished report, Dept. of Latin, University of Stellenbosch.

BRUWER, SURETHA. 1982. With the aid of the computer. Paper read at CASA Colloquium Didacticum, UCT.

BURKART, EDWARD I. and Grace Storall Burkart. 1986. Towards an authoring system for pre-electronic English. CALICO Journal 3.3, 11-13, 36.

BURKHARDT, HUGH, Rosemary Frazer and others. Undated ca. 1985. Design and development of programs as teaching material. Great Britain: Council for Educational Technology on behalf of the Microelectronics Education Programme.

BURLING, ROBBINS. 1982. An introductory course in reading French. In: F.W. Blair (Ed.), Innovative approaches to language teaching. q.v.

CHAPELLE, CAROL and Joan Jameson. 1986. Computer-assisted language learning as a predictor of success in acquiring English as a second language. TESOL Quarterly $20.1,27-46$.

CLAASSEN, JO-MARIE. 1989A:. The use of the micro-computer as an aid in students' understanding of Latin language and literature in a multilingual society. Per Linguam 5.1, 33-41.

CLAASSEN, JO-MARIE. 1989b. Tussentydse verslag, studieverlof tweede semester 1989. Unpublished report, Dept. of Latin, University of Stellenbosch.

CLAASSEN, JO-MARIE. 1988. Experiments in the teaching of introductory Latin at University level. S.A. Journal of Higher Education 2.1, 35-40.

COOK, V.J. ca. 1984. Bridging the gap between computers and language teaching. British Council, unpublished. 
CULBERTSON, JACK A. and L.L. Cunningham. 1986. Microcomputers and education. Chicago Ill.: Chicago U.P.

CULLEY, G.R. 1972. Computer-assisted instruction and Latin: beyond flashcards. Classical World 72.7, 393-401.

CULLEY, GERALD R. 1989. Liber: a tool for transition. Unpublished paper kindly lent by author, Dept. of Foreign languages and literatures, Delaware University, Newark DE.

DAVIES, ALAN. 1983. Computer-assisted language testing. Report to the British Council's English Teaching Advisory Committee, unpublished.

DAVIES, G. 1982. Authoring techniques and computer-assisted language learning. How can the teacher make the best use of the microcomputer?. In: D. van der Vyver, Ed.: Computers in education: Proceedings of SACCE 82, Stellenbosch, 439-451.

EMANUELLI, A.J. 1986. Artificial intelligence and computer-assisted language learning. VEA Papers in Linguistics 25/6, 43-56. Reported in: Language Teaching $1987,324$.

FOX, JEREMY ca. 1983. Humanistic CAL: Teachers' needs and learners' needs in the design and use of computer-assisted language learning systems. British Council, unpublished.

GEENS, DIRK. 1984. Computers and language education: a case for cognitive learning. ITL 66, 49-60. Reported in Language Teaching 1985 - 525.

HART, STEPHEN. 1989. What university students think of CALL in language courses. CALLBOARD 11.

HIGGINS, JOHN. 1983. Computer-assisted language learning. Language Teaching 16.2, 102-114.

HIGGINS, JOHN. 1983. Reading and risk-taking: a role for the computer. English Language Teaching Joumal 38.3, 192-198.

HIGGINS, JOHN \& Tim Johns. 1984. Computers in language learning. London: Collins.

HSRC: ED. RESEARCH PROGRAMME. 1983. Report of the work committee: the computer in education and training, Parts 3 and 4, Pretoria, HSRC.

JONES, CHRISTOPHER and S.V.E. Fortescue. 1987. Using computers in the language classroom. London: Longman.

KERSCHENBAUM, P.E.G. 1986. "SCIO". Classical World 79.5, 319-122.

KRASHEN, D. and Tracey D. Terrell. 1983. The natural approach: language acquisition in the classroom. Oxford: Pergamon.

KUSSLER, RAINER. 1989. Literatuuronderrig deur middel van 'Hiperteks'. SA Tydskrif vir Taalonderig 23.1, 72-88.

LAST, REX W. 1984. Language teaching and the microcomputer. Oxford: Blackwell.

LEARNING LATIN SUPPORT GROUP. 1987ff. Learning Latin Newsletter, (continually updated) School of Classics, University of Leeds, Leeds LS2 9JT. 
LOCATIS, CRAIG and Francis D. Atkison. 1984. Media and technology for education and training. Columbus, Ohio: Merrill.

LOUW, J.P. 1989. Words and meanings - a semantic problem. Akroterion 34, 3\&4, 238243.

MALAN, CARINA. 1988. Rekenaarhulp as moontlike oplossing vir probleme wat eerstejaarstudente ondervind. Proceedings, Third annual conference and workshop on excellence in teaching and learning in higher education, Stellenbosch.

MURRAY, JANET H., Douglas Morgenstern \& Gilbert Furstenburg. 1989. The Athena language-learning project. Design issues for the next generation of computer-based language learning tools. In: W.M. Flint Smith (Ed.). Modern technology in FL Education. Lincolwood Ill., Nat Textbook Co.

NOVAK, JOSEPH D. and D. Bob Gowin. 1984. Learning how to learn. Cambridge: C.U.P.

ODENDAAL, M. 1982. Second-language learning and computer-assisted language instruction (CALI). In: Van der Vyver (Ed.) Proceedings (q.v.), 403-404.

PAPERT, SEYMOUR. 1980. Mindstorms: Children, computers, and powerful ideas. Brighton: Harvester.

PARAMSKAS, D.M. 1986. Artificial intelligence in computer-assisted language instruction. Canadian Modern Language Review 42.3, 619-628.

PHILLIPS, M.K. 1983a. Technical terminology and the creation of lexical meaning. Paper presented at GERAS colloquium, Paris. The British Council, unpublished.

PHILLIPS, MARTIN. 1983b. Towards a taxonomy of CALL program types and a heuristic for software development. The British Council, unpublished.

PHILLIPS, M.K. 1984a. Approaches to the design of language teaching software. The British Council, unpublished.

PHILLIPS, MARTIN K. 1984b. Towards a framework for the development of computerassisted language learning. Cahiers de l'APLIUT 3.4, 16-30.

PHILLIPS, MARTIN K. 1985. Intelligent CALL and the QWERTY phenomenon: a rationale. System 13.1, 1-8.

PHILLIPS, MARTIN. 1986. Communicative language learning and the microcomputer. Mexico City: British Council Papers.

REEVES, THOMAS C. and Richard, M. Lent. 1982. Levels of evaluation for computerbased instruction. Paper presented at A.G.M. of American Educational Research Association. Eric reports ED, 217870.

REINKING, DAVID and Robert Schreiner. 1985. The effects of computer-mediated text on measures of reading comprehension and reading behaviour. Reading Research Quarterly, report in Language Teaching 1986, 343.

ROBINSON, BRENT. 1985. Microcomputers and the language arts. Milton Keynes: Open U. Press.

RUBENSTEIN, JUDITH G. 1987. DISCO. Classical World 81.1, 31-32. 
RUSSELL, ROSALIE M. 1984. The computer's capacity for flexible response utilised in second language learning. Babel (Australia) 19.3, 29-36.

SCANLAN, RICHARD T. 1971. Computer-assisted instruction: Plato in Latin. Foreign language Annals 5, 84-89.

SILBERMAN, CHARLES E. 1970. Crisis in the classroom: the remaking of American education. New York: Random House.

SMITH, FRANK. 1983. The promise and threat of microcomputers for language learners. TESOL 83, reported in Resources in Education 22.3, March 1987.

VAN DER VYVER, D. (Ed.). 1982. Proceedings: SA Congress on computers in education. Stellenbosch: INTUS.

WHITELAW, M.W. 1984. Effective teaching of artificial languages. Babel 19.2, $32 \mathrm{ff}$.

WIECHERS, G. 1982. Computer-assisted instruction in the SA context. In Van der Vyver (Ed.) (q.v.), 33-43.

\section{BIBLIOGRAPHIES AND SOFTWARE CATALOGUES}

BRITISH COUNCIL, THE. 1988. Computer-assisted language learning: an annotated bibliography. Pamphlet, BC Central information service, ETIC biliography, no. 2

CULLEY, GERALD. 1989. Latin software. Unpublished catalogue, with prices and comments. University of Delaware, Newark DE.

DECOO, WILFRIED. 1984. Bibliography on computer-assisted language instruction. In: W. Decoo (Ed.) Computer and language instructor: applications of interactive technology. Antwerp: $A B L A$ Papers.

ILECC. 1989. Software and publications: Output: Information technology in further and higher education newsletter. Inner London Educational Computer Centre, John Ruskin Street, London SE5 OPQ, 42-49.

LATOUSEK, ROBERT B. 1989. Survey of Latin instructional software for the microcomputer. Pamphlet, American Classical League, Teaching materials and Resource Center. Oxford $\mathrm{OH}$.

WIDA SOFTWARE. 1989. Catalogue. London, 2 Nicholas Gardens W2 5HY. Updated annually. 


\section{SOFTWARE}

The following lists only those programs that have been personally examined by the author and/or research assistants.

\section{Short critiques are included with each listing:}

CAIRNS, FRANCIS and Mark Haywood. 1988. Learning Latin Computer Package (LLCP). The School of Classics, University of Leeds, Leeds, LS2 9JT, Great Britain. (An approach towards an Artificial Intelligence system, which employs 'Golden Common LISP' to guide students toward careful analysis, parsing and metaphrasing of words in structural context. Extremely 'programmer-friendly, generating many hours of potential student effort, but with a potentially high 'boredom factor'. The AI system involved has the potential for electronic scholia research.)

CLAASSEN, D.M. \& J.-M., with E. Zietsman and S. Joubert. 1991. $C \cdot O N \cdot S \cdot N \cdot S \cdot U \cdot S$. BUCE, University of Stellenbosch. (Customizable didactic framework with randomizing principle for simple vocabulary and morphology drill, morphological analysis and cloze-type exercise in Latin endings. Takes any suitable (unformatted or text) data. Available in multilingual format, Latin, Afrikaans and English, but including some Xhosa.)

CAMBRIDGE LATIN COURSE. 1989. Computer programs. Cambridge Educational, CUP, The Edinburgh Building, Shaftesbury Road, Cambrdge CB2 2RU. (Interesting game formats, using computer graphics, aimed at very young pupils, with the specific intention of stimulating interest while teaching basics. Not suitable at university level.)

CULLEY, GERALD R. et al. 1991. Liber. Newark, DE: University of Delaware. (Hypertext with levels of elucidation of text. Potentially extremely useful). In preparation.

CULLEY, GERALD R. et al. 1984, 1987. Latin skills. Newark, DE: University of Delaware, (5 programs: 'Verb factory,' 'Mare nostrum,' 'Cursus honorum,' 'Translat,' 'Artifex verborum': generative routines, offering enough variation in approach to keep students' interest).

CULLEY, GERALD R. et al. 1989. Castra Variana. Newark, DE: University of Delaware (Latin adventure game based on the so-called Clades Variana. It works on the principle of Artificial Intelligence, prompting students when half-correct forms are typed in. The didactic rationale is that a student who thinks competitively in the target language will get to grips with that language. Developed together with a French version).

CULLEY, GERALD R. et al. 1989. Lector. Newark, DE: University of Delaware, (Adapted to various standard text books, generative routines, individualised feedback on right and wrong identifications.)

KERSCHENBAUM, PEG and Aaron. 1984. SCIO. New York, NY. Kerschenbaum, 60 Schriever Lane, New City, NY 10956. (Parsing drills, translation of sometimes bizarre Latin sentences generated by computer. The authors intend using the AI system here developed for specialised literary-stylistic research). 
LATOUSEK, ROBERT B. 1985, 1987. Latin flash drill; Latin vocab drill. Madison, WI: Centaur Systems (Morphology drill; vocabulary, either general or based on various standard text books, also basic grammatical exposition. Equates testing with teaching).

LATOUSEK, ROBERT B. 1988. Tutrix. Madison, WI: Centaur Systems. (Hypertext with free-exploration and tutorial modes, based on first 30 lines of Aeneid Book 4. Individual feedback is offered and students may also record notes while progressing through the program. Useful but limited in extent).

MALAN, C.A. \& S. MacDonald, with E. Zietsman, V. Raubenheimer and J.M. Claassen. 1988-1990. PISCINA. BUCE, University of Stellenbosch. (Linear teaching program with meticulous error-feedback, using colour change to inculcate Latin sentence structure, with initial analysis leading to synthesis. Available in Afikaans, but with two optional English-medium lessons included).

TATARSKY, PAUL. 1989. Escape from Pompeii. Madison, WI: Centaur Systems. (Trivial computer graphics adventure, with no intrinsic value for Latin teaching).

RUBENSTEIN, JUDITH. 1984. DISCO. Rubenstein, 7394 Westmoreland Drive, St. Louis, MO 63119. (Practice format: generation of paradigms; game format: challenging the student to produce specific forms; underpinned by an AI system. It has a potentially high boredom factor.)

SCANLAN, R.T. 1976-8. Beginning Latin: PLATO-style lessons on mainframe, as formerly installed at University of Western Cape. Basic morphology testing and drill. Now being updated to PC format. (Morphology drill and testing, translation, rather dull).

TESSERA, INC. undated. Latin certamen practice. American Classical League. (Randomised practice questions for specialised ACL schools' competition, available on graded levels; too specialised for general application).

WISC-WARE. undated. GLOSSA. Wisc-Ware, Academic computing Center, University of Wisconsin-Madison, WI 53706. (Hypertext authoring system, allowing input of text and levels of commentary for student use in non-directed way. At the time of examination, the system broke down and the present author could not regain access; apparently not yet finally polished.) 